\title{
The social work voice: How could unions strengthen practice?
}

Amy Ross

Amy Ross is a Massey graduate with both a Bachelor's and Master's Degree in Social Work and is a registered social worker. Amy worked for 14 years in the community sector as a social worker during which time she developed concerns over the working conditions of social workers and the impact of this on clients. This led her to work on addressing this issue and into the union movement where she is currently a union organiser for the PSA and the coordinator of the Social Workers Action Network. She is passionate about social work and social workers and dedicated to working ensuring our community has the best representation possible.

\section{Abstract}

Social workers have many different demands placed upon them daily. From a necessity to consistently engage in professional development and reflection through to the requirement to challenge social injustice and strive for social change, much is made of our ethical responsibilities and practice standards. This is as it should be due to the complex and demanding nature of our work. Yet far less is said about how social workers can effectively meet these strong commitments and who can support us to do so. The question of who 'advocates for the advocates' remains side-lined in the continuing development of our profession. This article examines unionism and how it may provide the support and advocacy needed to progress some of the long-standing issues faced by the social work community, as well as some of the key obstacles to this. In addition, an overview of the Social Workers Action Network (SWAN) within the Public Service Association (PSA) is provided to examine how these conceptual dilemmas are being dealt with in practice.

\section{Introduction}

It is internationally recognised that social workers are often low paid, can work very long hours with heavy, complex case loads and frequently have to juggle the demands of managers, clients and their professional body and/or registration board (Asquith, Clark, \& Waterhouse, 2005). Ross (2011) also found that there are ongoing issues in ensuring a distinct and valued social work identity within the workplace. Both of these are seen to impede successful, ethical and sustainable practice.

That these issues continue to be topical for social workers was seen in the recent flurry of conversation within the Aoteoroa New Zealand Association Social Work forum on the very issue of unionisation. It was the first time there had been such an outpouring of discussion on this forum and illustrated the breadth of people's concern. The themes of this discussion centre around the issues of union representation, if it is needed and where it is how best to achieve it in a way which ensures our unique identity is realised, and that our pay and conditions reflect our skills, commitment and standards. The questions and comments that flooded this forum about who could provide this and what it may look like are the same 
kinds of questions that I had been asking and investigating for some time and led to the writing of this article.

Evidence that suggests most social workers are drawn to the work to make a real difference or significant social change (Harlow, 2004; Ross, 2011). Barriers which prevent the achievement of these goals can lead to what is commonly referred to in the social work arena as 'burnout.' Frustration, exhaustion, helplessness and despair are all symptoms of burnout and are seen most often in social workers who are facing "organisational issues such as workload pressures" (Van Heugten, 2009, p. 441). Burnout has been identified as leading to a variety of negative outcomes from high staff turnover to more serious effects including depression, withdrawal and addiction (Baker, 2002).

The language of self-care tends to be widely utilised when speaking of support for social workers, as is personal supervision. These are good things and by no means do I seek to undermine their importance for social workers' wellbeing. It's simply that in all that discourse it is rare to hear anything about how we can achieve wellbeing as a profession, beyond our own role, or even our agency through collective organising and collective action. This article will question whether union activity could improve social workers' welfare by working on fundamental issues such as decent pay, workload balance, paid professional development and clear career pathways.

Alongside (and some may argue contributing to) some tenuous pay and conditions for social workers is the long debated issue of social worker identity. From the early approach of the Charitable Organisation Society through to the current day where managerialism and professionalisation are common catch phrases, social work has evolved a long way and this has contributed to social work being difficult to define (Haynes \& White, 1999; Lundy, 2004). There has been notable discussion within the literature on this matter, such as the Rank and Hutchison study in 2000 which found that one of the most important things social workers wanted from their leadership was ability to "clearly define the profession to ourselves and to others" (p.49). The meticulously documented Scottish Executive report also raised this topic, making an urgent call for social work "to clarify its professional identity" (Asquith, et al., 2005 p. 2).

The impacts of the lack of strong professional identity are manifold. The most basic of these is isolation. That is, without a coherent sense of identity we as social workers can be isolated from each other and from any sense of ourselves as being part of a profession which has a unique and valuable skill set. If we do not see ourselves as skilled professionals connected to a broader network of practitioners (regardless of their field of practice) who deserve basic standards of recognition and employment, this can leave us undervaluing our own expertise and therefore potentially having them undervalued by employers and funders. This underrating of social work can contribute to situations such as some community sector organisations employing qualified social workers at similar and lesser rates than checkout staff at some supermarkets, i.e. less than the living wage.

Moreover, this lack of strong identity can allow social workers to be limited by their organisational culture to the point where we simply follow agency dictates regardless of whether or not they are in line with social work ethics and values. If our ethical standards are not clear and we are not strongly unified around them by ensuring they are woven into 
our job descriptions and collective agreements, they can easily fall away. As Hughes and Wearing (2007) comment:

For many social workers this sense that their professional identity is limited by their organisational role comes as a surprise. Their social work education has been about not just instilling in them the skills, knowledge and values of social work but also in socialising them into the profession. That they are not able to fulfil all of the potential of their professional identity in the organisation that now employs them challenges many people... (p.10).

Thus the second question which this article addresses is: Could a growth in unionisation and the utilisation of union skills in collective organising improve our sense of ourselves and thereby enhance our practice? What are the challenges to this being successful?

\section{Social work ethics and standards}

As social workers we have ethics, principles and standards that we are responsible for upholding. Whether these be those from Aotearoa New Zealand Association of Social Workers (ANZASW), the Social Work Registration Board (SWRB), the International Federation of Social Workers (IFSW) or indeed all three. How ethics and standards are portrayed by these three bodies differs in presentation, wording and emphasis, but contain some basic points of connection. There are on-going discussions regarding these differences and their significance for social work that are important to have, yet for the purposes of this article I will lay that discussion aside to focus on three points of general overlap.

1. Social justice: Social workers have a responsibility to use their skills and knowledge to work towards social justice and promoting necessary social change within wider society.

2. Human rights: Social workers must be concerned with the existence and expression of human rights for every person, family and community.

3. Responsibility to agencies: Social workers have an obligation to ensure agency policies and procedures are not in conflict with social worker ethics and standards and are challenged appropriately if they are.

Many have argued that it is this moral/political emphasis that is one of the key elements that marks social work as unique from other professions, though they draw upon many of the same skill sets (Bisman, 2004; Dominelli \& McLeod, 1989; Payne, 1999). O’Brien (2009) deftly summarises this when he states:

Without explicit attention to social justice, social work becomes something else. It is not social work in either a historical or contemporary sense. Moreover without that attention, it would fail to meet both its international definition and its ethical requirements. (p. 78).

Even those who do not consider social work to be an inherently political activity recognise the significance of ethical principles and social justice as applicable to social work and social workers (Myer, 1981). Hence it can be argued that overall our ethical standards and commitments have wide acceptance from the social work community.

A significant amount of the social work literature on enacting these ethics and standards is focused on individual clients and our responsibilities to them. There is considerably less emphasis on broader systemic social justice work and almost no discussion on what may 
assist us to work sustainably and effectively towards social justice and human rights on all levels in real-world environments. Even within literature which critiques social justice work by social workers and makes the point for more action on issues such as poverty, treaty-based issues or access to services, these works often lack real, practical steps for social workers to implement these actions in the face of difficult or restrictive work environments. Indeed some practitioners have postulated that social workers cannot implement their ethical standards to any significant degree within the current employment milieu (Dominelli \& McLeod, 2004; Lymbery \& Butler, 2004).

It would appear that despite the thread of social justice and human rights being a strong binding force for the social work profession, we have yet to find solutions to address the reality that implementing our ethical standards is something we can struggle to do alone.

\section{Unions}

The New Zealand Ministry of Business, Innovation and Employment (MBIE) describes unions as "organisations that support employees in the workplace by acting as an advocate for them and standing up for their rights. They often act as a middle person between employers and employees. Unions bargain for conditions in collective agreements and help employees with work related issues" (MBIE, 2013). This is more or less what unions say about themselves, for example the Public Service Association, New Zealand's largest union states:

Unions are about workers coming together collectively to deal with their issues at work, in their industry and in wider society...The right of workers (and employers) to form and join organisations of their own choosing is an integral part of a free and open society. It is a right that is enshrined in both national and international law. (Public Service Association, 2010).

The Council of Trade Unions (CTU), to which the majority of Aotearoa/ New Zealand-based unions affiliate, lists the following four principles that are fundamental to the CTU and affiliates:

- the right to useful employment, to social security, to social justice, human rights and equal opportunity;

- the right to organise and to form and join Trade Unions;

- the right to bargain collectively with the employer;

- the right to strike.

The union movement has a fascinating and detailed international and national history, most of which cannot be contained within this article. It is worth mentioning however some key points in union history here in Aotearoa/New Zealand which are not well known. In 1821 Maori workers organised collectively to go on strike for the right to be paid in money, the first such event in our history (Together Union, 2013). Likewise union organising by Samuel Parnell, amongst others, achieved the eight-hour working day (ibid). Unions such as the PSA also began over time to have a presence in shaping events in wider society by participating in social justice movements such as Halt All Racist Tours (HART) and campaigns opposing nuclear testing (O'Connor, 2013). The key point to this history being the journey to rights at work being inextricably linked over time to rights as a whole, to the broader issues of social justice and fairness, intersecting the union movement with the goals of the social work community. 
One of the greatest challenges to the union movement came from the passing of the Employment Contracts Act in 1991. This act removed much of the legislative backing for unions and (even according to the most conservative of reviewers) decreased wages and rates such as penal and overtime (Morrison, 2006). Union membership dramatically declined over this time and led to a restructuring of many unions to find new ways of working and engaging and empowering membership as well as working within a hostile political environment (O'Connor, 2013).

Today, out of the crisis of the 1990s a new kind of union movement has arisen (O'Connor 2013). More democratic and member driven, a fundamental element of most unions today is their willingness to campaign on issues that affect their members and / or erode basic rights for workers. These may take the shape of representation and support for individuals in disputes with their employer, collective bargaining and broader social campaigns. Some recent campaigns have been around the establishment of a living wage, obtaining minimum wage for sleepovers, fair pay for caregivers, organising members to be heard on changes to the Employment Relations Act (currently awaiting its third reading in Parliament) which look to remove key rights for workers, as well as taking a test pay equity case (which is before the Court of Appeal at the time of writing this article). In all of these examples resources and energy were mobilised to identify the issues, inform and educate people on the issues, bring people together and empower them to take action.

\section{How can unions strengthen social work practice?}

The commitments within social work ethical and practice standards regarding social justice and social change are shared by the main unions as indicated above. This core link is worth emphasising when considered against the representation of unions by some media as fundamentally communist agencies with dominating anti-capitalist agendas which override other issues. In reality, anti-capitalist agendas may be held by some union members, but structurally the unions themselves maintain commitments not to one political system but to social justice, equity and fairness. As we share the above commitments, the core goals and commitments of the social work community and the union movement seem to overlap; lending credence to the idea that the culture and goals of the union movement are compatible with social work practice. Nevertheless there needs to be more than simply a shared overarching vision for the argument for the unionisation of social workers to be a strong one, for as a profession we require real and practical steps to assist in implementing our commitments as a collective.

I will cover two specific ways in which unions can support social work practice and some of the challenges to achieving these. There are undoubtedly more, many of which would develop and grow as the rate of unionisation grows amongst social workers, yet it is beyond the scope of this article to anticipate and cover all of these.

\section{Workplace rights}

The first way that unions can strengthen practice has to do with our fundamental rights as employees. In my experience social workers are not well versed at thinking of themselves as needing advocacy or representation, despite having multiple layers of responsibility and demands to fulfil on the job. There is evidence that challenges such as increasing client numbers with little to no increase in staffing or other funding and no consistent, cross-sector standards of employment for social workers have not changed much over the last 30 years (Chow \& Ellis, 1980, New Zealand Council of Christian Social Services, 2009). The lack of 
advocacy and a collective organising response such as a union is able to coordinate has contributed to our inability to enshrine employment rights which safeguard our ability to maintain optimal ethical standards.

One example of how unions can protect our fundamental rights as employees is found in the move towards compulsory social work registration and the subsequent need to meet core competencies as set out by either the Social Work Registration Board or ANZASW for this registration. One of these competencies is to engage in Continuing Professional Development (CPD) each year. Despite this requirement many social workers (particularly in the community sector) do not have any provision or resourcing in their job descriptions for professional development, meaning this work has to be undertaken at one's own expense and in one's own time.

If social workers were to join a union and gain the capacity to bargain collectively and raise the profile of our practice obligations, professional development options could be negotiated and preserved within an employment agreement. Essentially the industrial advocacy structures of a union can be utilised to help establish core conditions for employing a social worker. This in turn allows employing agencies to turn to funders and push for appropriate levels of funding for their staff. Social workers need not feel that they cannot ask for decent conditions as their agency is cash poor and they do not wish to place strain upon it. If we work together with the union and with funders, our collective strength and bottom lines become a bargaining tool for our agencies as well, so that government or philanthropic trusts know that to obtain social workers to fulfil a contract they must be valued and paid fairly for their professionalism. This same strategy of negotiation for a collective agreement could be applied to long-neglected areas for social workers such as appropriate pay structures, leave entitlements, caseload limits, regular supervision and career progression pathways for every practice field.

Alternatively one social worker advocating for these improvements would likely fall victim to being ignored or ostracised, not to mention the possibilities for that individual to suffer exhaustion and disillusionment. By working together, a key strategy of unionisation, social workers can utilise the principle of solidarity to produce strong, ethical workplaces. The importance of this is underscored by the International Federation of Social Workers (2012) policy on the effective employment of social workers, where it states that:

A framework for supporting good practice needs to take account of ethical principles and ensure effective induction, supervision, workload management and continuing professional development (IFSW, 2012 p. 2).

\section{Strengthening our identity}

As raised earlier one of the struggles for social workers that remains unresolved is that of our identity. This debate has existed throughout recorded social work history (Dominelli \& McLeod, 1989; Lundy, 2004; Lymbery, 2001). One of the key elements in having a strong identity is having a recognisable voice which allows others to perceive what we do and what ethics and values we are informed by. This in turn provides us with the ability to identify and address relevant issues from a position of professional strength.

If we bring strong union representation into this equation what we can immediately achieve is the removal of the 'lone voice' feeling. Firstly you are connected to other social 
workers via either your collective agreement or by being connected to other unionised social workers from different sites and sectors. Secondly you have access to advocates and organisers that can facilitate the coordination of a social work voice on an issue, whether it is one that affects us as workers or one that affects our clients, community or society. For social work, with all its differences and complexities is practised in an employment setting and as such safeguards are needed for those who practise it.

Unions have a strong history of campaigning on issues that affect their members and their community. Access to that skill base can strengthen our capacity as social workers to try out our professional voice. As people who work with people from all walks of life we will often have first-hand experience and knowledge of how things such as policy or legislative decisions impact upon our communities. Most social workers will also have a good idea of the smaller-scale problems that can be caused by decisions or approaches by our own employers.

It is important to note at this point that our professional body, ANZASW, also has an important role in shaping and supporting professional identity for social workers. The argument for what unions can provide is not one which seeks to take this important role away from ANZASW or put forward an either/or argument. To provide a small example of how complementary the roles could be let us consider the ANZASW code of ethics for social workers. This is a document that our professional body spends considerable time and thought on developing and evolving so it is strong and relevant. This document and the work ANZASW puts into it ensures we have a clearly articulated, solid and unifying platform from which to work. The role of a unionised social work workforce with regard to this document would be to ensure that this code of ethics is woven through the employment agreement of a social work employee, protecting their right and ability to fully adhere to it. This work could not happen without both parties and has the potential to maximise the capacity for each social worker to practise in the best and most sustainable way possible. The possibilities for working in complementary ways appear to be extensive as both organisations want a strong, dynamic, valued social work profession.

One could argue that social workers should be standing up regardless of whether or not we are unionised, that each of us has a responsibility to speak up on issues of significance. This is true and identifying injustice is indeed part of our ethical framework. Nonetheless this argument ignores the reality that social workers are employees and many employees, whether we wish it or no, can be vulnerable to the whims of their employer. Contracts for government funding which many agencies employing social workers rely upon are often short term and based on organisations adhering to government defined performance indicators and outcomes (Carey, 2008; Lymbery, 2001). In practice this can mean social workers feel more precariously positioned in their jobs and government has a good deal of control over practitioners (Ferguson, 2008; Harlow, 2004). Payne (1999) summarises this feeling when he writes that "Many social workers feel more regulated by legislation, managerial control, bureaucratic systems and quality assurance mechanisms than they do by moral precepts"' (p.250).

Union involvement that provides direct support, resources and organisational coordination to social worker members across different practice fields could ensure we can work together more easily and speak to our agencies with a collective voice. This could assist 
in developing a more universal understanding of social work by employers and funders. Furthermore we can gain recognition of the fact that the social workers are ultimately informed by and have a responsibility to uphold our code of ethics and standards of practice. In turn social workers can provide critical feedback and assistance to employers in finding the most useful and effective ways of working towards shared goals for the wellbeing of our clients, our communities and ourselves. As the IFSW employment policy (2012, p.1) states:

A positive working environment is created where the values and principles of managers and social workers are consistent with each other and mutually reinforcing. There is substantial evidence that the most effective social work services are provided in situations where employers understand the social work task, respect their employees and are committed to implementing professional values.

\section{The challenges of unionisation}

To be clear, the idea of unionising social workers is not a new one. In 1980 a feasibility study commissioned by the New Zealand Association of Social Workers: Standards and Salaries Commission found there was 50\% support for a social work union, with a further $35 \%$ indicating that it would most likely be a good idea and only 15\% not supporting it (Chow \& Ellis, 1980). The issues discussed in the 1980 study traverse a number of issues that remain problematic today. For example low pay, the lack of consistent standards of employment for social workers in different practice fields, and no appreciable understanding of appropriate staff-to-client ratios are all mentioned (ibid).

Despite this report and others like it, unionisation has not previously occurred on a coordinated basis for social workers. In discussions with social work peers the issues of visibility, lack of clarity about which union, previous poor experiences and fears about industrial action affecting clients were all reoccurring concerns that appear to have interfered with the unionisation of social workers.

It is certainly true that there has been no clear union for social workers. When I originally cast around my peers for an appropriate union I was puzzled to discover that not only were they poorly unionised but where they were unionised they were scattered amongst different unions and hence almost invisible within them. Being appended on as an afterthought within union structures primarily designed for other industries or occupations will certainly not meet the needs of the social work community. It seemed more logical for social workers to join together within one union, or indeed even our own union so we could be more audible.

Upon investigation of the feasibility of a separate social work union it was quickly apparent that this was the least feasible option. Even if we got almost every social worker unionised, something notoriously difficult to do, the relatively small number ${ }^{1}$ and large spread of social workers would mean that having industrial organisers and resources on the

This holds regardless of what data set you draw social work numbers from, registered social workers, members of ANZASW or self identified social workers in the census. The numbers are all relatively small compared to existing union's capacity. The largest of these groups was the 2013 census data which showed that 18,327 individuals identified as social workers, with 3,465 of these people holding a recognised social work qualification (Statistics New Zealand, 2013). 
ground for every area with the same capability and leverage as the existing unions would be a logistical impossibility. Additionally it would mean going up against other unions and potentially dividing our social work community even further.

With this conclusion having been reached the next step was to look at existing infrastructure and what was needed to improve it. I wrote to the key unions social workers were involved with to raise some of the issues social workers were facing and asked them what could be done to improve their representation of the unique needs of social workers. I wanted to know how a big union could ensure that our unique needs were met.

Out of the responses I received it was the PSA who responded positively, acknowledging the validity of the points raised and offering the growing Community Public Service (CPS) sector of the PSA as a thriving example of how the PSA has grown beyond its original borders of the core public service to meet changing needs. With a long history of representing social workers within the state sector (Chow \& Ellis, 1980), covering social workers as a whole was a natural next step. Working alongside CPS organisers I realised the question did not end with what will the PSA do to make sure social workers' needs are met, but what would I do. Hence I decided to jump at the support offered by the PSA and develop the Social Workers Action Network (SWAN) to create a home for social workers within the PSA so we could come together under one banner.

SWAN is a now an active network within the PSA that is designed to organise around and advocate for the unique needs of social workers. PSA members who are social workers can join and together we decide on key issues or campaigns to improve the working life of social workers or campaign on key social justice issues. Even where we bargain alongside our colleagues from other disciplines, such as in the District Health Boards (DHB) SWAN aims to ensure that social work is not blurred by this association but strengthened and maintains a distinct voice in the strategic direction of these negotiations. SWAN ensures that social workers are not lost amongst other groups and how visible we are is up to how active we wish to be in our network. SWAN also offers the opportunity to deal with the other concerns that have been raised as obstacles to unionisation. We can educate union organisers, take up delegate and other responsibilities and be a part of creating the kind of union support we want.

\section{Summary}

Unionisation has real benefits for social work practice. Some of these, such as improved pay and conditions, could be an almost immediate and very tangible benefit in areas where we could simply get the critical mass of union members needed to initiate for a collective agreement. Some such as the strengthening of the social work professional identity to address broader issues are less immediate but will take work and commitment by both union organisers and social work members. (Like one of the PSA posters says 'union membership is like a gym membership, if you don't show up you don't get stronger'.) It will also take innovation and cooperation with other bodies such as ANZASW and the SWRB.

It is not my intent to portray unionisation as the 'silver bullet' for the social work community that will instantly resolve all the issues we collectively face. Nevertheless both the immediate and long-term benefits of the kind of union support the PSA is offering represent 
a real investment in the future of social work and could be an important tool in our kete of resources which support our profession.

\section{References}

Asquith, S., Clark, C., \& Waterhouse, L. (2005). The role of the social worker in the 21st century: A literature review. Edinburgh: Scottish Executive.

Baker, E. K. (2002). Caring for ourselves: A therapist's guide to personal and professional wellbeing. Washington: American Psychological Association.

Bisman, C. (2004). Social work values: The moral core of the profession. British Journal of Social Work, 34, 109-123.

Carey, M. (2008). Everything must go? The privatisation of state social work. British Journal of Social Work, 38(5), 918-935.

Chow, S., \& Ellis, L. (1980). A study of the employment of "social workers" in the voluntary sector and the feasibility of a national social services union. Unpublished report commissoned by the New Zealand Association of Social Workers, Standards and Salaries Committee. Privately held.

Dominelli, L., \& McLeod, E. (1989). Feminist social work. Basingstoke: Macmillian.

Ferguson, I. (2008). Reclaiming social work: Challenging neo-liberalism and promoting social justice. London: Sage.

Harlow, E. (2004). Why don't women want to be social workers anymore? New managerialism, postfeminism and the shortage of social workers in Social Service Departments in England and Wales. European Journal of Social Work, 7(2), 167-179.

Haynes, D., \& White, B. (1999). Will the 'real' social work please stand up? A call to stand for professional unity. Social Work, 44(4), 385-391.

Hughes, M., \& Wearing, M. (2007). Organisations and management in social work. London: Sage.

International Federation of Social Workers. (2012). Effective and ethical working environments for social work: The responsibilities of employers of social workers. Retrieved 1/4/2013 from: http:/ / ifsw.org/ policies/ effective-and-ethical-working-environments-for-social-work-the-responsibilities-of-employers-of-social-workers-3/.

Lundy, C. (2004). Social work and social justice: A structural approach to practice. Peterborough, Broadview Press.

Lymbery, M. (2001). Social work at the crossroads. British Journal of Social Work, 31, 369384.

Lymbery, M., \& Butler, S. (2004). Social work ideals and practice realities: An introduction. In M. Lymbery \& S. Butler (Eds.), Social work ideals and practice realities. Basingstoke: Palgrave Macmillan.

Morrison, A. (1996). The Employment Contracts Act and its economic impact. Retrieved 3/2/2014 from http:/ / www. parliament.nz/resource/0000000366.

Myer, C. (1981). Social work purpose: Status by choice or coercion? Social Work, 26(6), 74.

New Zealand Council of Christian Social Services. (2009). Facts about poverty in 2009. Retrieved 1/9/2010, 2010, from www.justiceandcompassion.org.nz.

New Zealand Ministry of Business Innovation and Employment. (2013). Retrieved 5/8/2013 from http:/ / www. dol.govt.nz/infozone/myfirstjob / resources.

O'Brien, M. (2009). Social work, poverty and disadvantage. In M. Connolly \& L. Harms (Eds). Social work: Contexts and practice (2nd ed). Auckland: Oxford University Press.

O'Connor, M. E. (2013). The State and the Union: An oral history of the PSA, 1984-2012. Wellington: Steele Roberts Aotearoa

Payne, M. (1999). The moral bases of social work. European Journal of Social Work, 2(3), 247-258.

Public Service Association (2010). PSA Overview. Retreived 3/2/2014 from http:/ /www.psa.org.nz/about-us/ who-we-are/ what-we-stand-for/.

Rank, M., \& Hutchison, W. (2000). An analysis of leadership within the social work profession. Journal of Social Work Education, 36(3), 487-502.

Ross, A (2011). Justice in action? Social work and social justice. MSW thesis, Massey University, Palmerston North, New Zealand.

Statistics New Zealand. (2013). Occupation. ANZSCO V1.1 Retrieved 3/2/2014 from http: / www.stats.govt.nz / searchresults.aspx?q=Occupation\%20(ANZSCO $\% 20 \mathrm{~V} 1.1)(1)(2)$.

Together Union. (2013). How your rights were won. Retrieved 2/2/2014 from http: / www.together.org.nz / aboutus / unionhistory.

Van Heugten, K. (2009). Thriving at work: Preventing occupational stress. In M. Connolly \& L. Harms (Eds). Social work: Contexts and practice (2nd ed.). Auckland: Oxford University Press. 